\title{
$\mathrm{UAV}$ 네트워크 환경에 적합한 위치기반 라우팅 프로토콜의 성능 분석
}

정회원 박 영 수 , 종신회원 정 재 일

\section{Performance Analysis of Position Based Routing Protocol for UAV Networks}

\author{
Youngsoo Park ${ }^{*}$ Regular Member, Jaeil Jung ${ }^{*^{\circ}}$ Lifelong Member \\ 요 약
}

네트워크 중심전의 실현을 위해 여러 체계들이 개발되고 있다. 그중에서 무인 항공기 체계는 군사적인 응용에 서 가장 주목을 받고 있다. 일반적으로 무인 항공기들은 임의로 애드혹 네트워크를 형성할 수 있을 뿐만 아니라 소스 노드와 목적지 노드사이의 홉수도 많이 줄일 수 있다. 하지만 무인 항공기 네트워크 환경은 높은 이동성, 높은 데이터 전송률, 실시간 서비스를 제공해야 하는 특성이 있다. 이러한 무인 항공기 네트워크의 요구사항에 동적으로 적응할 수 있는 멀티홉 라우팅 프로토콜의 설계가 요구되고 있다. 본 논문에서는 소스 노드와 목적지 노드 사이의 제일 짧은 지리적 거리를 사용하여 효율적이고 신뢰적인 전송을 하는 Geographic Routing Protocol 의 성능을 분석한다. Geographic Routing Protocol은 비디오 서비스를 제공하는 시나리오에서 TDMA 모델을 사 용하여 시뮬레이션을 수행하여 평가하였다. 시뮬레이션 결과 Geographic Routing Protocol은 기존의 MANET 라 우팅 프로토콜보다 패킷 수신율, 종단간 지연, 라우팅 트래픽 발생량 등 면에서 더 좋은 성능을 보였다.

Key Words : UAV networks, Video application, Geographical routing, Simulation, Performance analysis

\section{ABSTRACT}

Many systems are developing for the realization of NCW(Network Centric Warfare). UAV(Unmanned Aerial Vehicle) Network is attracting attention in a lot of military applications. In general, UAVs have the potential to create an ad-hoc network and greatly reduce the hops from source to destination. However, UAV networks exhibit unique properties such as high mobility, high data rate, and real time service. The routing protocols are required to design the multi-hop routing protocols that can dynamically adapt to the requirements of UAV network. In this paper we analyse Geographic Routing Protocol is based on geographical distance between source and destination for efficient and reliable transmission. Geographic Routing Protocol is evaluated in video service scenarios with TDMA model in our simulation. The simulation results show that the performance of Geographic Routing Protocol is better than the MANET Routing Protocol in terms of packet received ratio, end to end delay, and routing traffic sent.

\section{I. 서 론}

미래 전장은 모든 전투요소가 네트워크로 연결되 어, 실시간 정보를 공유하는 정보전 및 네트워크 중

\footnotetext{
한양대학교 전자컴퓨터통신공학과(\{netmansys and jijung\} @hanyang.ac.kr), $\left({ }^{\circ}\right.$ : 교신저자)

논문번호 : KICS2011-11-525, 접수일자 : 2012년 2월 8일, 최종논문접수일자 : 2012년 2월 13일
} 
심전(NCW : Network Centric Warfare ${ }^{[1]}$ 으로 변 화하기 때문에 통신의 역할 및 중요성이 증대되고 있는 상황이다. 미래의 전장 환경의 양상인 지해공 및 우주, 사이버 5 차원 전장과 정밀살상/파괴 및 원 거리/분산 전투 상황에서 감시정찰을 통한 지형지물 및 공격 목표물에 대한 정확한 정보의 실시간(근실 시간) 공유가 중요하다.

그중에서 무인 항공기에서 수집된 임무 영상 정 보와 비행기의 상태정보를 지상 관제장비에 손실 없이 전송시켜 필요한 정보를 획득하고, 지상 관제 장비에서는 무인 항공기로 전송된 정보들을 분석하 고 그 정보들로부터 항공기의 상태를 체크하여 적 절한 임무 수행 명령을 주어 무인 항공기를 적절히 운용하는 것에 그 목적이 있다.

이러한 정보들은 데이터의 용량이 크기 때문에 높은 데이터 전송률을 요구하게 되며, 이러한 정보 들을 송수신하는 데이터의 지연, 손실, 지터 등에 대해 서로 다른 QoS(Quality of Sevice) 요구사항 을 만족시킬 수 있어야 하며, 서비스별 요구사항에 동적으로 적응할 수 있는 멀티홉 라우팅 프로토콜 의 설계를 요구하고 있다.

$\mathrm{UAV}$ 통신환경에서의 멀티홉 라우팅 프로토콜들 은 MANET 라우팅 프로토콜을 기반으로 하고 있 으며 응용서비스 특성에 맞춰 최적화 설계를 하는 것이 일반적이다. 그러나 기존의 MANET 라우팅 프로토콜에서 대표적으로 $\mathrm{AODV}, \mathrm{DSR}, \mathrm{OLSR}^{[2]}$ 와 같은 프로토콜들은 경로의 설정과 유지과정 때 문에 많은 지연시간과 네트워크 자원을 소모하게 된다. 그러므로 $\mathrm{UAV}$ 사이의 거리가 멀고 고속으로 이동하고 토폴로지 변화가 많고 고용량 데이터를 보내야하는 UAV 네트워크 환경에 적합하지 않다.

일반적으로 군용 장비에는 GPS 등 측위 장비들 이 탑재되어서 노드의 실시간 위치 정보를 이용하 여 목적지 노드까지의 경로를 찾는 위치기반 라우 팅 프로토콜들을 많이 연구하고 있다. 본 논문에서 는 UAV 통신환경에서 실시간 멀티홉 포워딩을 통 해 메시지를 효율적이고 신뢰적으로 제한된 지연 시간 내에 전송하도록 보장하는 $\mathrm{GRP}(\mathrm{Geographic}$ Routing Protocol) 대한 성능 분석을 한다.

본 논문의 구성은 다음과 같다. 2장에서는 위치 기반 라우팅 프로토콜의 장단점과 UAV 통신환경에 적용 가능한 위치기반 라우팅 프로토콜들을 소개한 다. 3장에서는 GRP 프로토콜과 $\mathrm{AODV}, \mathrm{DSR}$, OLSR 프로토콜들과의 성능 평가를 위한 시뮬레이 션 환경과 성능 분석 결과를 보여준다. 4 장에서는
본 논문에 대한 결론과 향후 연구 방향을 제시한다.

\section{II . 위치기반 라우팅 프로토콜}

\section{1. 위치기반 라우팅 프로토콜의 장단점}

위치기반 라우팅 프로토콜은 부가적인 지리적 위 치정보를 이용하여 목적지 노드의 위치로 가는 경 로를 계산하여 패킷을 전송하는 방식이다. 이러한 라우팅 프로토콜은 전송 패킷의 해더에 포함된 목 적지 노드의 위치정보와 1-Hop 범위 내에 있는 이 웃노드들의 위치정보만을 이용하여 경로 결정을 한 다. 따라서 각 노드들은 자신의 위치정보를 필요로 하며, 위치정보는 GPS, Active Badges, Cricket ${ }^{[3]}$ 등의 위치센싱 기법들을 이용하여 획득할 수 있다.

위치기반 라우팅 프로토콜의 장점을 살펴보면 아 래와 같이 요약할 수 있다. 첫째, 지역적인 (localized) 정보를 이용하여 경로를 선정하고 오버 헤드를 줄일 수 있다. 위치정보를 이용하는 라우팅 프로토콜들은 일반적으로 경로의 설정과 유지과정이 필요하지 않고 소스 노드가 주변 노드들의 위치정 보를 이용하여 목적지 노드의 위치로 가는 경로를 계산하여 패킷을 포워딩(forwarding)한다.. 둘째, 확 장성이 용이하다. 전체 네트워크의 토폴로지에 대한 정보와 유지과정이 필요 하지 않기 때문에 네트워 크의 크기에 구속 받지 않는다.

위치기반 라우팅 프로토콜의 난제중의 하나가 목 적지 노드와 주변 노드의 정확한 위치정보를 얻는 것이다. 목적지 노드와 주변 노드의 정확한 위치정 보가 없으면 라우팅 패킷은 목적지 노드에 제대로 전달할 수 없다. 따라서 위치기반 라우팅을 수행하 기 위해 선행적으로 위치 서비스와 비콘 서비스가 제공되어야 한다. 위치 서비스는 위치기반 라우팅을 수행하기 위해 필요로 하는 목적지 노드의 위치정 보를 제공하게 된다. 목적지 노드의 위치정보를 알 게 되면 소스 노드는 자신과 주변 이웃 노드의 위 치정보를 기반으로 라우팅 경로를 설정하게 된다. 비콘 서비스는 주변 이웃 노드의 위치정보를 제공 하는 기능으로써, 이는 주기적으로 자신의 ID, 위치 등 정보를 포함하는 비콘 메시지를 주변에 브로드 캐스트 한다.

결과적으로 위치기반 라우팅은 위치서비스와 비 콘 서비스를 사용함에 따라 발생하는 오버헤드, 위 치 서비스에 따른 전송 지연 및 위치 정보의 정확 도에 따른 라우팅 실패 등 불리한 요소들을 갖는다. 


\subsection{1 위치 서비스}

위치 서비스는 이동 노드들의 위치 정보를 제공 하는 서비스이다. 대부분 위치기반의 라우팅 프로토 콜은 목적지 노드의 정확한 위치 정보를 알고 있다 고 가정한다. 하지만 현실에서 위치정보를 제공하는 GPS 시스템은 여러 가지 영향 요인으로 인한 오차 로 목적지 노드의 위치가 정확하지 않다. 특히 Greedy forwarding을 사용하는 위치기반 라우팅 프 로토콜은 위치의 오차에 의해 라우팅 성능에 큰 영 향을 받는다.

위치 서비스는 두 가지 종류가 있는데 하나는 Proactive 방식의 위치 서비스이고 다른 하나는 Reactive방식의 위치 서비스이다. Proactive 방식의 위치 서비스는 노드들이 주기적으로 위치 정보를 교환하는 방식을 사용하고 Reactive 방식의 위치 서 비스는 위치 정보가 필요할 때만 위치 정보를 교환 한다.

Proactive 방식의 위치 서비스는 Location database systems $^{[6]}$ 와 Location dissemination systems ${ }^{[7]}$ 으 로 분류할 수 있다. Location database systems에서 는 네트워크에 있는 특정한 노드들이 위치 데이터 베이스 서버로 동작하고 다른 노드들에게 위치 정 보를 제공해 준다. 한 노드가 다른 위치로 이동 했 을 때 이 노드는 자신의 새로운 위치 정보로 위치 데이터베이스 서버를 업데이트 한다. 한 노드가 다 른 노드의 위치 정보를 요구할 때, 주변의 데이터베 이스 서버에 질의 메시지를 보내어 요구되는 노드 의 위치정보에 대한 회답 메시지를 받는다. Location dissemination systems에서는 네트워크에 있는 모든 노드들이 주기적으로 주변 노드들의 업 데이트 된 위치 정보를 주고받는다. 따라서 한 노드 가 다른 노드의 위치 정보를 요구할 때, 이 정보는 그 노드의 위치 정보 테이블에서 검색할 수 있다.

RLS(Reactive Location Service)는 한 노드가 다 른 노드들의 위치 정보를 요구 할 때만 위치 정보 를 제공하는 서비스이다. RLS에서는 소스 노드가 목적지 노드의 위치정보를 요청할 때, 먼저 자신의 주위에 있는 노드들에게 위치 정보를 요청한다. 일 정한 시간(timeout) 동안 응답이 없으면, 소스 노드 는 위치 정보 요청을 전체 네트워크에 플러딩 (flooding) 한다. 인접 노드가 위치 정보 요청 패킷 을 수신하였을 때 해당되는 위치정보가 없으면 위 치 요청 패킷을 재전송하고 위치 정보가 있으면 위 치 정보 응답 패킷을 보낸다. 이 동작과정은 $\mathrm{DSR}$ 에서의 소스 라우팅과 비슷한 방식으로 각 중간 노
드들은 자신의 위치정보를 헤더에 삽입한다. 또한, 위치 요청 정보에 응답할 때 위치 요청 패킷이 전 달해온 경로의 역방향으로 위치 응답 패킷을 보낸 다. DSR과의 차이점을 살펴보면 RLS는 위치정보를 확보하려고 하나 $\mathrm{DSR}$ 은 완벽한 라우팅 경로를 결 정하기 위함이다. 또한, 먼저 위치 정보를 주변 노 드에게 물어보는 것과 중간 노드들의 응답을 허용 하는 것은 $\mathrm{RLS}$ 와 $\mathrm{DSR}$ 이 공동으로 갖고 있는 특징 이다.

\subsection{GRP(Geographic Routing Protocol) ${ }^{[5]}$}

GRP(Geographic Routing Protocol)은 MANET 위치기반 라우팅 프로토콜 중에서 Proactive방식의 프로토콜이다. 기본적으로 모든 노드들은 GPS를 탑 재하여 자신의 위치정보를 알고 있다. 라우팅 할 때 소스와 목적지사이의 제일 짧은 위치 거리를 선택 한다. Quadrants를 사용하여 노드가 이동하거나 주 변 노드의 변화에 의해 생성된 새로운 위치 정보를 Flooding 하여 트래픽을 최적화한다. Hello 메시지 를 통해 주변노드의 위치 정보를 알 수 있고 만약 경로가 손상되면 Backtracking 기능으로 새로운 경 로를 탐색한다. GPR 라우팅 프로토콜의 주요한 6 가지 기능의 특징은 아래와 같다.

\subsubsection{GRP Quadrant}

Route Flooding에 의한 트래픽을 감소하기 위해 서 GRP는 네트워크를 여러 개의 Quadrants로 분할 한다. 모든 Quadrants는 정사각형으로 구성되며 Quadrant의 크기는 사용자 임의로 정의할 수 있다. 그림 1은 네트워크를 여러 개의 Quadrants로 분할 하는 방법이다. 자신의 위치 정보를 알면 쉽게 자신 이 어느 Quadrant에 속하는지를 알 수 있고 4개의 Quadrants는 Higher Level Quadrant를 형성한다. 예를 들어 $\mathrm{Aa} 1, \mathrm{Aa} 2, \mathrm{Aa} 3, \mathrm{Aa} 4$ 가 각각 Level 1에 속한다면 $\mathrm{Aa}$ 는 Level 2에 해당하는 Quadrant이다. 마찬가지로 A는 Level 3에 속하는 Quadrant이다. 


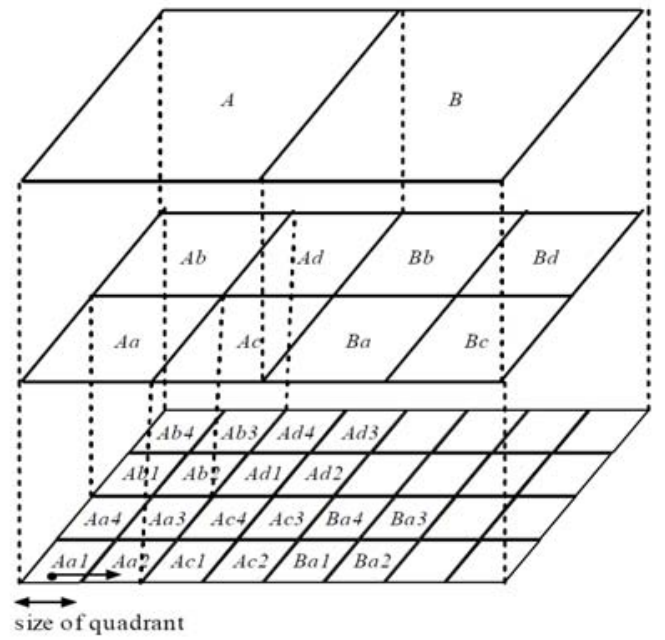

그림 1. GRP 라우팅 프로토콜 Quadrant 분할 개념

Fig. 1. Concept of quadrants in GRP routing protocol

\subsubsection{GRP Flooding}

네트워크를 초기화할 때 모든 노드들은 자신이 전송 가능한 목적지 노드의 위치정보를 Flooding 메시지를 통해서 얻는다. 노드가 일정한 거리를 이 동하거나 새로운 Quadrant로 넘어왔을 때 Flooding 메시지를 통해서 위치정보를 업데이트 한다. Flooding 하는 네트워크의 범위는 Quadrant에 의해 제약되며 해당되지 않는 Quadrant에서 받은 패킷을 받게 되면 그 패킷을 버리게 된다.

○ 만약 한 노드가 자신의 Quadrant에서 이동하면 그 Quadrant안의 노드들만이 Flooding 패킷을 교환한다.

만약 한 노드가 Quadrant Aa1에서 $\mathrm{Aa} 2$ 로 넘 어갔다면 Level 2의 $\mathrm{Aa}$ 에 있는 노드들이 Flooding 패킷을 교환한다.

안약 한 노드가 Quadrant Aa2에서 Ac1로 넘 어갔다면 Level 3 의 $\mathrm{A}$ 에 있는 노드들이 Flooding 패킷을 교환한다.

\subsubsection{GRP Routing Database}

$\mathrm{GRP}$ 에서 만약 노드들이 서로 같은 Quadrant에 있으면 정확한 위치 정보를 라우팅 데이터베이스에 저장한다. 예를 들어 그림 2에서 $\mathrm{N} 1$ 은 $\mathrm{N} 2$ 의 정확 한 위치 정보를 라우팅 데이터베이스에 저장한다. 만약 노드들이 서로 다른 Quadrant에 있으면 인접 한 Quadrant에 있는 노드들의 Quadrant 정보들을 라우팅 데이터베이스에 유지한다. 예를 들어 N1은 N3가 Quadrant B에 있다는 정보를 가지고 있고 S 가 Quadrant $\mathrm{Aa}$ 에 있다는 정보도 가지고 있다.
A B

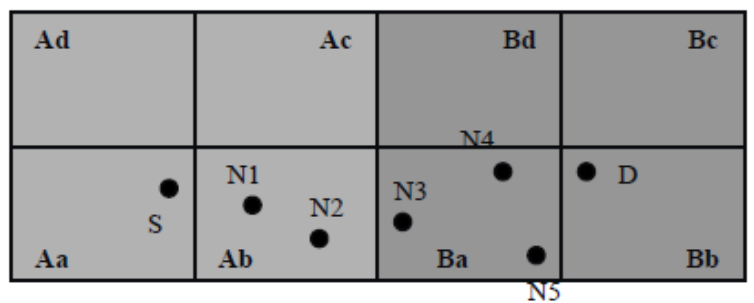

그림 2. GRP 라우팅 테이블

Fig. 2. GRP routing table

\subsubsection{GRP Hello Protocol}

모든 노드들은 자신의 존재여부와 이동 상태를 주기적으로 알리기 위해 자신의 주변 노드들에게 자신의 위치정보를 Hello 메시지에 담아서 Broadcast 한다. Hello 메시지는 위치알림 메시지에 는 노드의 ID, 타임스탬프(timestamp), 위치, 이동 속도 및 방향 등 정보를 포함한다. 노드는 이웃 노 드로부터 Hello 메시지를 수신하면 위치 테이블에 이웃 노드 정보를 추가하고, 이웃 노드 정보의 유효 시간을 설정한다. 유효시간 내에 해당 이웃 노드로 부터 Hello 메시지를 수신하게 되면 위치 테이블의 이웃 노드 상태 정보는 새롭게 업데이트 된다. 유효 시간이 만료되면, 노드는 이웃 노드가 통신 반경에 서 존재하지 않는다고 판단하고, 위치 테이블에서 해당 노드에 대한 정보를 삭제한다. Hello 메시지는 일정한 주기로 보내게 되며 주기의 설정은 Mobility 에 따라서 조절하여야 한다. 일반적으로 Mobility가 높으면 Hello 메시지 주기를 짧게 한다.

\subsubsection{GRP Routing Lookup}

소스 노드가 패킷을 목적지로 보내려고 할 때 목 적지 노드가 소스 노드와 같은 Quadrant에 있으면 소스 노드는 자신의 이웃 노드중에서 목적지 노드 와 가장 가까운 이웃 노드를 선택해서 패킷을 포워 딩한다. 이 패킷을 받은 이웃 노드는 또 자신의 이 웃 노드 중에서 목적지와 가장 가까운 노드에게 포 워딩한다. 이러한 과정은 패킷이 목적지에 도착할 때까지 반복된다.

만약 소스 노드와 목적지 노드가 다른 Quadrant 에 있다면 소스 노드는 소스 노드와 목적지 노드가 인접한 Quadrant가 될 수 있는 상위 레벨 Quadrant 를 알 수 있다. 소스 노드는 목적지의 Quadrant로 들어갈 수 있는 노드와 가장 가까운 이웃 노드에게 패킷을 포워딩한다. 


\subsubsection{GRP Backtracking}

패킷을 포워딩하는 과정에서 만약 경로가 손상되 면 패킷은 그 전의 포워딩 노드로 다시 돌아가서 새로운 경로를 찾게 된다. Backtrack 패킷을 받은 노드는 목적지 노드와 가장 가까운 다음 노드로 패 킷을 포워딩 한다. 만약 후보 경로에서도 계속 목적 지로 가는 경로가 없다면 Backtrack 패킷은 계속 그 전의 포워딩 노드로 전달되고 만약에 소스 노드 까지 전달되게 되면 그 패킷은 버리게 된다.

\subsection{GPSR (Greedy Perimeter Stateless Routing) ${ }^{[4]}$}

GPSR은 이웃 노드의 위치 정보만을 이용하여 패킷을 전송하는 라우팅 기법이다. 라우팅 기법은 토폴로지의 변화율과 네트워크상에 존재하는 라우터 의 수에 따라 확장성이 결정된다. GPSR은 로컬 토 폴로지에 대한 정보만을 유지함으로써 다양한 네트 워크의 변화에 유연하게 대응할 수 있다. GPSR은 라우팅 시에 이웃 노드의 지리 정보를 적극적으로 사용함으로써 Greedy forwarding과 Perimeter forwarding이라는 두 가지 기법을 사용한다.

\subsubsection{Greedy forwarding}

패킷을 전달하는 소스 노드는 이웃 노드들의 위 치를 알고 있으면 이웃 노드 중 목적지와 위치상 가장 가까운 노드를 다음 전달 노드로 선택하여 패 킷을 전송한다. 이러한 규칙으로 라우팅이 이루어지 면 패킷은 목적지에 도달할 때까지 지리상 가장 가 까운 노드들의 경로를 설정하게 된다.

간단한 beacon 알고리즘을 사용하여 이웃 노드의 위치를 파악할 수 있다. 노드들은 주기적으로 자신 의 위치 정보를 beacon 패킷에 담아 자신의 주변 노드들에게 전송한다. Time-out 시간까지 이웃 노드 로부터 beacon이 다시 전송되지 않으면 해당 이웃 노드는 자신의 전송 가능 영역 밖으로 이동했다고 간주한다. Beacon 재전송 주기는 길어질수록 이웃 노드의 위치 정보의 정확성은 감소한다. 하지만 노 드의 이동 속도가 빠를수록 재전송 주기는 짧아져 야 한다. Beacon 알고리즘에 의한 오버헤드를 줄이 기 위해 노드들은 전송하는 모든 패킷에 자신의 위 치 정보를 담아 보낸다. 그러나 Greedy forwarding 에는 한 가지 큰 결점이 존재한다. 전송 노드의 이 웃 노드 중에 전송 노드보다 목적지에 가까운 노드 가 존재하지 않을 경우 패킷을 전송할 수 없다.

\subsubsection{Perimeter forwarding}

송신 노드는 패킷을 전송하기 위해 자신의 통신 영역을 탐색하지만 이웃 노드가 존재하지 않으면 패킷을 전송하지 못한다. 송신 노드는 자신의 통신 영역 근처의 노드를 통한 경로의 존재 여부를 계산 하여 존재할 경우 해당 노드로 패킷을 전송한다. 이 러한 방식을 Perimeter forwarding이라고 한다. Perimeter forwarding은 Right-hand rule이라고도 불 린다. 이 규칙에 따라 송신 노드로부터 전송되는 패 킷은 목적지 노드로 전달된다.

\section{III. 시뮬레이터 환경 설정}

본 논문에서는 $30 \mathrm{Km} \times 30 \mathrm{Km}$ 크기를 가지는 두 개의 그룹 내의 UAV와 지상 장비간의 통신망 을 가정하여 GRP 프로토콜과 $\mathrm{AODV}, \mathrm{DSR}, \mathrm{OLSR}$ 프로토콜의 성능을 비교 분석하였다. 성능 분석은 OPNET 17.1 시뮬레이터를 사용하여 수행하였다.

\section{1 시뮬레이터 환경 설정}

본 논문은 $\mathrm{UAV}$ 를 이용하여 공중과 지상의 정보, 감시 및 정찰(ISR) 체계 간 네트워크 기반의 영상 정보용 공용데이터링크에 관한 것이다. 본 논문에서 는 선진국 영상정보용 공용데이터링크의 시뮬레이터 환경으로 데이터 전송률을 $0.2 \mathrm{Mbps}-45 \mathrm{Mbps}$ 로 구성 하였다. 그리고 $10 \mathrm{~km}$ 고도로부터 최대 LOS로 예상 되어지며 $\mathrm{Ku}$ 대역에서 운용 가능하되 또는 그 이상 의 대체 $\mathrm{RF}$ 대역들 $(\mathrm{X}, \mathrm{Ku}, \mathrm{Ka})$ 안에서 작동하도록 장차 성장 수용력을 지원할 것이다. ${ }^{[8]}$ 예상되는 data link budget에서 의해 본 논문에서는 OPNET 표준 TDMA 모델을 $\mathrm{UAV}$ 통신환경에 적합하게 $\mathrm{PHY}$ 규격과 $\mathrm{MAC}$ 규격을 수정하였다. 그리고 어플 리케이션 모델에서 Video Conferencing (Light) 모 델을 사용하였으며 Incoming Stream Interarrival Time (seconds)을 None으로 설정하여 단 반향 트 래픽만 보내도록 하였다. 표 1 은 본 논문에서 적용 한 시뮬레이터 환경 설정을 보여주고 있다.

본 논문에서는 모든 노드들의 위치 벡터와 시간 동기화 정보를 GPS모듈을 통해 제공한다고 가정하 고 또한 LOS에서 Free Space 경로손실만 고려한다. 
표 1. 시뮬레이터 환경

Table 1. Simulation environment

\begin{tabular}{|c|c|c|c|}
\hline Layer & Process Model & \multicolumn{2}{|c|}{ Parameter } \\
\hline \multirow{2}{*}{$\begin{array}{l}\text { Applica } \\
\text {-tion }\end{array}$} & \multirow{2}{*}{$\begin{array}{c}\text { Video } \\
\text { Conferencing } \\
\text { (Light) }\end{array}$} & Packet Size & 17280Byte \\
\hline & & Tx Interval & 0.1 Second \\
\hline Network & $\begin{array}{l}\text { Routing } \\
\text { Protocol }\end{array}$ & \multicolumn{2}{|c|}{ AODV, DSR, OLSR, GRP } \\
\hline \multirow{4}{*}{ MAC } & \multirow{4}{*}{ TDMA } & Frequency & $15 \mathrm{Ghz}$ \\
\hline & & $\begin{array}{c}\text { Channel } \\
\text { Bandwidth }\end{array}$ & $16 \mathrm{Mhz}$ \\
\hline & & Tx Power & $13 \mathrm{~W}$ \\
\hline & & $\begin{array}{c}\text { Receiver } \\
\text { Sensitivity }\end{array}$ & $-80 \mathrm{dBm}$ \\
\hline \multirow{3}{*}{ PHY } & \multirow{3}{*}{ Pipe Line Stage } & Data Rate & $16 \mathrm{Mbps}$ \\
\hline & & Modulation & QPSK \\
\hline & & $\begin{array}{c}\text { Antenna } \\
\text { Gain(UAV) }\end{array}$ & $14 \mathrm{dBi}$ \\
\hline
\end{tabular}

\section{2 운용 시나리오 설정}

그림 3은 운용 시나리오의 구성도이다. 운용 시 나리오는 2개 그룹으로 구성된 네트워크 토폴로지 에서 그룹 1에서의 $\mathrm{UAV}($ Source)로부터 그룹 2에서 의 팀 $\mathrm{A}$ 중의 지상장비(Destination)에게 영상정보를 보내주는 시나리오이다. UAV들 간의 최대통달거리 는 $43 \mathrm{Km}$ 이고 지상 장비와 UAV간의 최대통달거리 는 $8.5 \mathrm{Km}$ 이다. Source와 UAV G2-1는 각각 그룹 1 와 그룹 2 의 영역에서 랜덤하게 이동하며 UAV TA-1와 Destination은 팀 A의 영역에서 랜덤하게 이동한다. Source에서의 영상정보는 UAV G2-1와 UAV TA-1의 포워딩을 통해 Destination에게 전달 된다.

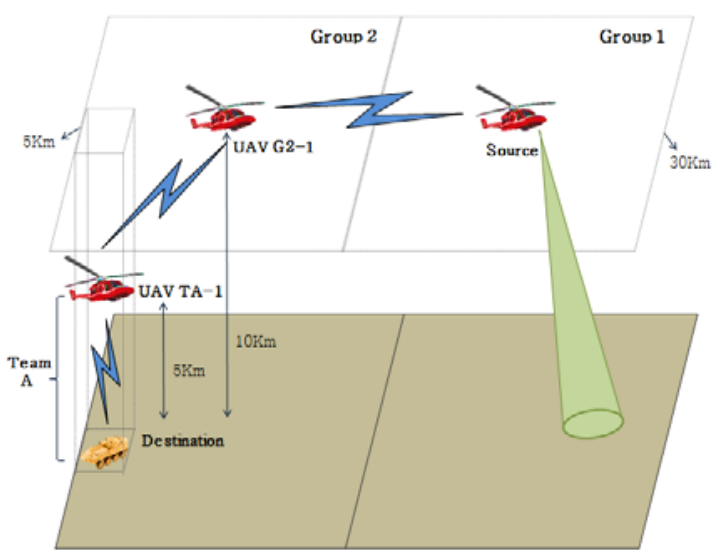

그림 3. 시뮬레이션 시나리오

Fig. 3. Operational scenario

본 논문에서는 표 2 와 같이 시나리오 환경을 설
정하고 $\mathrm{AODV}, \mathrm{DSR}, \mathrm{OLSR}, \mathrm{GRP}$ 로 각각 1시간 시뮬레이션을 수행하였다.

표 2. 운용 시나리오 환경

Table 2. Opeational scenario environment

\begin{tabular}{|c||c|c|c|c|}
\hline \multicolumn{1}{|c||}{ Parameter } & \multicolumn{4}{|c|}{ Value } \\
\hline Object & Source & UAV G2-1 & UAV TA-1 & $\begin{array}{c}\text { Destina- } \\
\text { tion }\end{array}$ \\
\hline Speed & $42 \mathrm{~m} / \mathrm{sec}$ & $42 \mathrm{~m} / \mathrm{sec}$ & $42 \mathrm{~m} / \mathrm{sec}$ & $21 \mathrm{~m} / \mathrm{sec}$ \\
\hline Altitude & $10 \mathrm{Km}$ & $10 \mathrm{Km}$ & $5 \mathrm{Km}$ & $1.5 \mathrm{~m}$ \\
\hline Mobility & $\begin{array}{c}\text { Random } \\
\text { Waypoint }\end{array}$ & $\begin{array}{c}\text { Random } \\
\text { Waypoint }\end{array}$ & $\begin{array}{c}\text { Random } \\
\text { Waypoint }\end{array}$ & $\begin{array}{c}\text { Random } \\
\text { Waypoint }\end{array}$ \\
\hline $\begin{array}{c}\text { Simulation } \\
\text { Time }\end{array}$ & \multicolumn{4}{|c|}{1 Hour } \\
\hline
\end{tabular}

3.3 시뮬레이션 결과 및 성능 분석

본 논문에서는 4 가지 라우팅 프로토콜의 성능을 분석하기 위하여 다음과 같은 성능 파라미터를 사 용하였다.

○ 패킷 수신율(Packet Received Ratio): 목적지 노드에서 받은 패킷 량과 소스 노드에서 보낸 패킷 량의 비 값이다.

옹단간 지연(End to End Delay): 종단간 지연 은 소스 노드에서 전송한 패킷이 목적지 노드 에 도착하였을 때 발생한 지연이다.

○ 라우팅 트래픽 송신량(Routing Traffic Sent): 각 라우팅 프로토콜이 동작할 때 경로를 관리 하기 위해 발생하는 제어 메시지의 량이다.

그림 4에서는 UAV와 지상 장비가 각각 Random waypoint Mobility 모델을 사용하였을 경우, 네 가 지 라우팅 프로토콜이 경로의 선정 및 유지의 차이 에 의해 서로 다른 패킷 평균 수신율을 가진다는 것을 볼 수 있다.

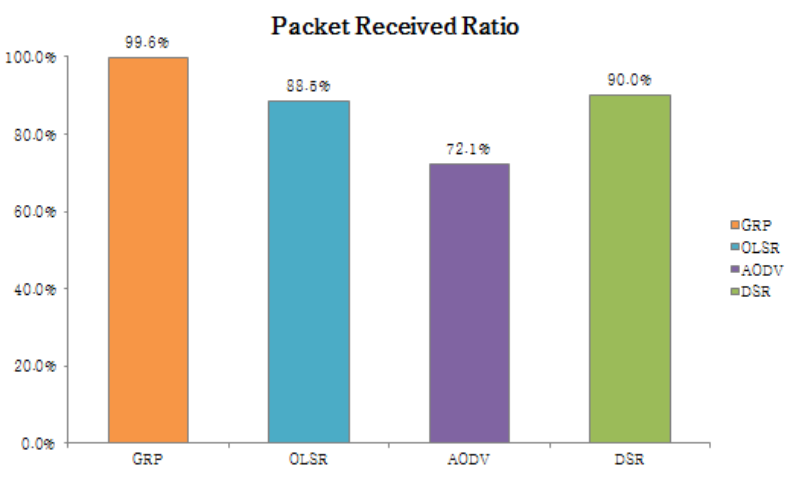

그림 4. 패킷 수신율

Fig. 4. Packet received ratio 
그림 4로부터 GRP는 $99.6 \%$ 수신율을 보여주지 만 $\mathrm{DSR}, \mathrm{OLSR}, \mathrm{AODV}$ 는 각각 90\%, $88.5 \%$, $72.1 \%$ 의 수신율을 보여주고 있다. GRP는 완전한 주변노드의 정보만 가지고 패킷을 포워딩하기 때문 에 본 논문에서와 같이 고속으로 이동하고 네트워 크 토폴로지가 자주 변화되는 특성에 적합하다. 하 지만 $\mathrm{AODV}, \mathrm{DSR}, \mathrm{OLSR}$ 은 목적지로 가는 완전한 경로의 유지가 필요하므로 이동성에 의해 경로가 끓어지면 기존의 경로를 삭제하거나 또는 새로 경 로를 찾아야 하는 과정이 필요하기 때문에 토폴로 지가 자주 변화되는 특성에 적합하지 않다는 것을 볼 수가 있다.

그림 5에서는 네 가지 라우팅 프로토콜의 방식의 차이에 따라 서로 다른 평균 종단간 지연을 갖는 것을 볼 수 있다. 그림 5로부터 Proactive 방식인 $\mathrm{GRP}$ 와 OLSR은 각각 0.1초 0.08 초의 지연시간을 가지고 Reactive 방식인 $\mathrm{AODV}$ 와 $\mathrm{DSR}$ 은 각각 0.16 초와 0.14 초의 지연시간을 가진다. Proactive 방 식인 라우팅 프로토콜들은 네트워크의 전체 노드로 가는 경로를 항상 탐색하기 때문에 패킷을 보내려 고 할 때 목적지로 향하는 경로를 알고 있다면 직 접 보내면 된다. 하지만 Reactive 방식인 라우팅 프 로토콜들은 패킷을 보내려고 할 때만 경로를 탐색 하여 Proactive 방식보다 지연시간이 일반적으로 많 다. 임무를 수행하는 UAV들은 높은 파워를 가지기 때문에 서로간의 통신거리가 길다. 그러므로 적은 노드수로 전체 네트워크를 커버할 수 있고 이러한 특성을 가진 네트워크에는 Proactive 방식의 라우팅 프로토콜들이 적합하다는 것을 볼 수 있다.

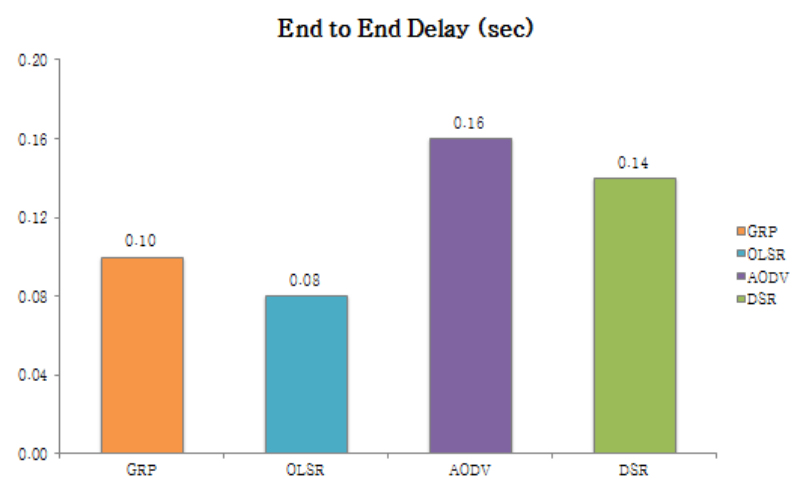

그림 5. 종단간 지연

Fig. 5. End-to-end delay

GRP와 OLSR은 같은 Proactive 방식이지만
GRP는 주변노드들의 위치정보만 Proactive 방식으 로 유지하고 경로는 주변노드의 위치정보에 의해 계산되며 포워딩하는 노드도 같은 방식으로 목적지 노드로 가는 경로를 찾아야 하기 때문에 일정한 시 간이 소모된다. 하지만 OLSR은 네트워크의 모든 노드로 가는 완전한 경로를 유지하기 때문에 지연 시간이 가장 짧다.

그림 6에서는 소스 노드가 목적지 노드로 패킷을 보내기 위해 네 가지 라우팅 프로토콜을 사용하여 경로를 찾고 경로에 관한 정보들을 관리하는데 발 생하는 평균 라우팅 트래픽 송신량을 보여주고 있 다. 그림 6 로부터 $\mathrm{GRP}$ 는 $458 \mathrm{bits} / \mathrm{sec}$ 의 라우팅 트 래픽을 발생하고 $\mathrm{OLSR}, \mathrm{AODV}, \mathrm{DSR}$ 은 각각 $680 \mathrm{bits} / \mathrm{sec}, 1033 \mathrm{bits} / \mathrm{sec}, 4736 \mathrm{bits} / \mathrm{sec}$ 의 라우팅 트 래픽을 발생하는 것을 볼 수 있다. GRP는 Network Address 대신에 위치정보를 사용하여 라우팅 경로 를 찾기 때문에 패킷 오버헤드가 다른 프로토콜보 다 작다. 그리고 경로의 유지과정이 없고 주변노드 들의 위치정보만 주기적으로 교환하기 때문에 발생 하는 라우팅 트래픽이 제일 작다. OLSR은 MPR를 통해 플러딩 메시지의 트래픽을 줄일 수 있지만 목 적지로 향하는 경로가 끓어지면 전체 네트워크에 알려주고 새로운 경로를 찾는데 필요한 트래픽이 발생한다. AODV와 DSR은 Reactive 방식이지만 경로를 관리에 의해 목적지로 향하는 경로가 끓어 지면 그 경로에 있는 노드에 에러 메시지를 보냄으 로써 해당 경로를 삭제하고 새로운 경로를 찾는 과 정이 노드의 높은 이동성에 의해 빈번하게 발생하 게 된다. DSR은 패킷 헤더에 소스 노드로부터 포 워딩 노드의 정보를 모두 삽입하므로 라우팅 트래 픽이 제일 많은 것을 볼 수가 있다.

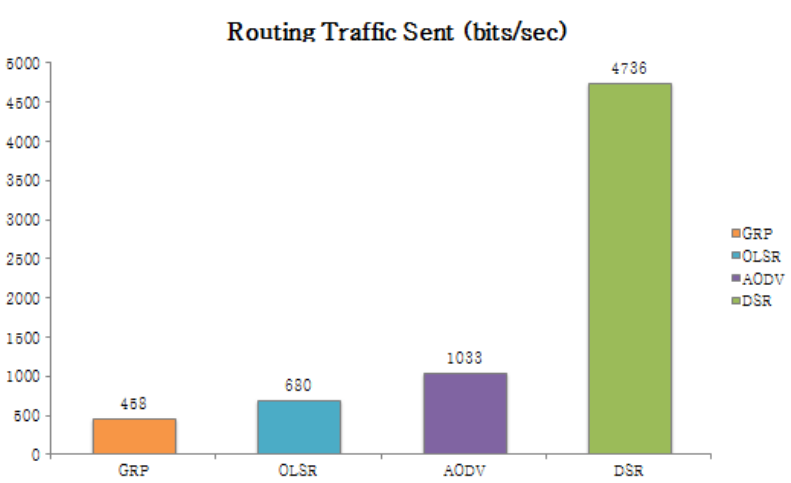

그림 6. 라우팅 트래픽 전송량

Fig. 6. Routing traffic sent 


\section{IV. 결 론}

본 논문에서는 UAV 네트워크 환경에 적합한 위 치기반 라우팅 프로토콜의 장단점을 살펴보았고 2 가지 적용 가능한 위치기반 프로토콜을 소개하였다. 시뮬레이션 결과에서 GRP 위치 기반 라우팅 프로 토콜은 패킷 수신율, 종단간 지연과 라우팅 트래픽 량 측면에서 기존 MANET 라우팅 프로토콜인 $\mathrm{AODV}, \mathrm{DSR}, \mathrm{OLSR}$ 보다 월등한 성능을 보여주었 다.

향후에는 Store and Forward Buffer를 이용하여 목적지 노드로 데이터를 전달하기 위한 적절한 이 웃 노드가 존재하지 않으면 메시지를 일정한 시간 동안 버퍼링하고 통신 범위 내에 새로운 이웃 노드 가 나타나거나 혹은 기존 이웃 노드의 이동 방향의 변화 등 이벤트에 따라 해당 메시지에 대한 라우팅 을 재시도 하는 방식을 사용하여 GRP의 성능을 향 상시키려고 한다. 그리고 시나리오에서 UAV 통신 영역의 확대와 노드수의 증가에 따라 GPSR, GRP 등 위치기반 라우팅 프로토콜과의 좀 더 자세한 성 능 비교를 수행하겠다.

\section{참 고 문 헌}

[1] 정종문, 박규철, 원태연, 오의환, 고동철, 홍석 준, 윤창배, 김호, 박의영, "영상정보용 공용데 이터링크 표준화 발전방향” 한국통신학회지 제 28권 제4호, pp.2-54, 3월 2011년.

[2] A. Boukerche, "Performance Comparison and Analysis of Ad Hoc Routing Algorithms," IEEE Int'l Congress on Pastoral Care and Counselling, pp. 171-178, 2001.

[3] J. Hightower and G. Borriello, "Location Systems for Ubiquitous Computing," IEEE Computer, vol. 8, no. 34, pp. 57 -66, August 2001.

[4] Karp, B. and Kung, H.T., "Greedy Perimeter Stateless Routing for Wireless Networks", in Proceedings of the Sixth Annual ACM/IEEE International Conference on Mobile Computing and Networking (MobiCom 2000), pp. 243-254., August, 2000.

[5] OPNET 17.1, www.opnet.com

[6] J.Li, J.Jannotti, D.De Couto, D. Karger, and R. Morris. "A scalable location service for geographic ad hoc routing", In Proceedings of the ACM/IEEE International Conference on Mobile Computing and Networking (MOBICOM), pp.1377-1384, 1999.

[7] T.Camp, J.Boleng, and L. Wilcox. "Location information services in mobile ad hoc networks", In Proceeding of the IEEE international Conference on Communications (ICC), pp.3318-3324, 2002.

[8] 정종문, 김동구, 고동철, 안찬호, 김형찬, “영상 정보 수집 자산용 주파수 공유 통신망 표준화 방안“, 방위사업청. 2008.

박 영 수 (Youngsoo Park) 정회원

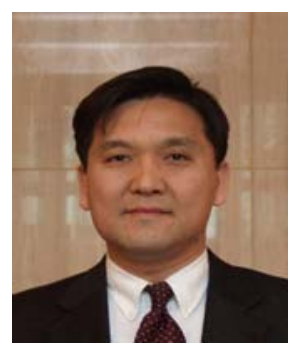

1986년 2월 한양대학교 전자공 학과 공학사

1990년 5월 미국 켈리포니아 주 립대 전산학 이학석사

2006년 2월 현재 국방기술품질 원 연구원

2007년 3월 현재 한양대학교 전자컴퓨터통신공학과 박사과정 <관심분야> 통신망관리, 위성통신시스템

정 재 일 (Jaeil Jung) 종신회원

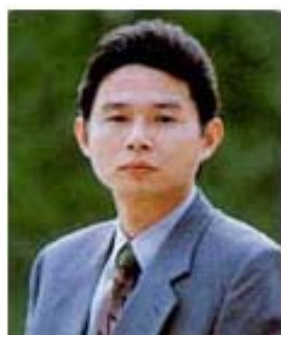

1981년 2월 한양대학교 전자 공학과 공학사

1984년 2월 한국과학기술원 공학석사

1993년 2월 프랑스 국립전기

통신대학교 공학박사

1993년 현재 한양대학교 전자

컴퓨터통신공학과 교수

<관심분야> 차세대 네트워크, Qos 보안 